Article

\title{
Aromatic Constituents from the Stems of Astragalus membranaceus (Fisch.) Bge. var. Mongholicus (Bge.) Hsiao
}

\author{
Jia Hao ${ }^{1,+}{ }^{\dagger}$ Jian $\mathrm{Li}^{2,+}$, Xiaoxia $\mathrm{Li}^{2}$, Yanxia Liu ${ }^{1}$, Jingya Ruan ${ }^{1}$, Yongzhe Dong ${ }^{1}$, Yi Zhang ${ }^{1,2, *}$ \\ and Tao Wang $1,2, *$ \\ 1 Tianjin Key Laboratory of TCM Chemistry and Analysis, Institute of Traditional Chinese Medicine, \\ Tianjin University of Traditional Chinese Medicine, 312 Anshan Road, Nankai District, Tianjin 300193, China; \\ synthia2010@sina.com (J.H.); liuyanxia210@163.com (Y.L.); Ruanjy19930919@163.com (J.R.); \\ dongyongzhe44@hotmail.com (Y.D.) \\ 2 Tianjin State Key Laboratory of Modern Chinese Medicine, 312 Anshanxi Road, Nankai District, \\ Tianjin 300193, China; beyondwill@126.com (J.L.); huifeidedouzi@yeah.net (X.L.) \\ * Correspondence: zhwwxzh@263.net (Y.Z.); wangtao@tjutcm.edu.cn (T.W.); \\ Tel./Fax: +86-22-5959-6163 (Y.Z. \& T.W.) \\ + These authors contributed equally to this work. \\ Academic Editor: Derek J. McPhee \\ Received: 5 February 2016 ; Accepted: 10 March 2016 ; Published: 16 March 2016
}

\begin{abstract}
Four new aromatic constituents, astraflavonoids A (1), B (2), C (3), and astramemoside A (4), along with sixteen known ones 5-20 were obtained from the stems of A. membranaceus (Fisch.) Bge. var. mongholicus (Bge.) Hsiao. Their structures were elucidated by chemical and spectroscopic methods. Among the known isolates, $\mathbf{1 4}$ was obtained from the Astragalus genus for the first time, while 7-12, 18-20 were isolated from the species for the first time. The effects of the compounds obtained from the plant on glucose consumption were analyzed in differentiated L6 myotubes in vitro, whereby compounds $1,2,3,7,8,10,11,14,15$ and 18 displayed significant promoting effects on glucose consumption in L6 myotubes. Among them, the activities of 1, 2 and $\mathbf{7}$ were comparable to that of insulin, which suggested that these compounds may be involved in glucose metabolism and transport.
\end{abstract}

Keywords: Astragalus membranaceus (Fisch.) Bge. var. mongholicus (Bge.) Hsiao.; stem; structure elucidation; aromatic constituents; L6 cells; glucose consumption

\section{Introduction}

Astragalus membranaceus (Fisch.) Bge. var. mongholicus (Bge.) Hsiao (AM), belongs to the Astragalus genus of the Leguminosae family. The main chemical constituents of the plant are flavonoids and terpenoids. During the course of our studies, 14 oleanane type saponins, including eight new ones, named astroolesaponins $\mathrm{A}, \mathrm{B}, \mathrm{C}_{1}, \mathrm{C}_{2}, \mathrm{D}, \mathrm{E}_{1}, \mathrm{E}_{2}$, and $\mathrm{F}$, have been obtained from its stems, and some of them showed depressing effects on triglyceride levels in sodium oleate-induced HepG2 cells [1]. During our continued research on this species, twenty aromatic constituents, including four new ones, were isolated from AM using $\mathrm{SiO}_{2}$ gel, ODS, Sephadex LH-20 column chromatography (CC) and preparative HPLC chromatography (Prep HPLC), and their structures were clearly determined by chemical and spectroscopic methods $\left({ }^{1} \mathrm{H}-\mathrm{NMR},{ }^{13} \mathrm{C}-\mathrm{NMR},{ }^{1} \mathrm{H}-{ }^{1} \mathrm{H}\right.$ COSY, HSQC, HMBC, UV, IR, CD, and MS). Based on the evidences of previous activity reports on the Astragalus genus [1], the glucose consumption effects of the isolates were examined. 


\section{Results and Discussion}

The $70 \%$ EtOH extract of AM was subjected to solvent partition, chromatographic isolation, and chemical and spectral analysis. As a result, four new compounds (Figure 1), astraflavonoids A-C (1-3) and astramemoside A (4), along with sixteen known ones (Figure 2), kaempferol (5) [2], kaempferol3-O- $\beta$-D-glucoside (6) [3], kaempferol-3-O-(2-O- $\alpha$-L-rhamnopyranosyl)- $\beta$-D-glucopyranoside (7) [4], kaempferol-3,7-di-O- $\beta$-D-glucopyranoside (8) [5], rhamnocitrin-3-O- $\beta$-D-glucopyranoside (9) [6], rhamnocitrin-3-O-neohesperoside (10) [7], complanatuside (11) [8], quercetin-3-O- $\beta$-D- neospheroside (12) [9], genistein (13) [10], sophorabioside (14) [11], calycosin (15) [12], odoratin-7-O- $\beta$-Dglucopyranoside (16) [13], (-)-liquiritigenin (17) [14,15], maltol- $\beta$-D-glucopyranoside (18) [16], 2,6-dimethoxy-4-hydroxyphenyl-1-O- $\beta$-D-glucopyranoside (19) [17], and benzyl- $\alpha$-L-arabinopyranosyl $\left(1^{\prime \prime} \rightarrow 6^{\prime}\right)-\beta$-D-glucopyranoside (20) [18] were obtained from it. Among the known isolates, compound 14 was isolated from the Astragalus genus for the first time, and 7-12, 18-20 were isolated from the species for the first time. Herein, the isolation and identification of these compounds are described, as well as their effects on glucose consumption in L6 cells.

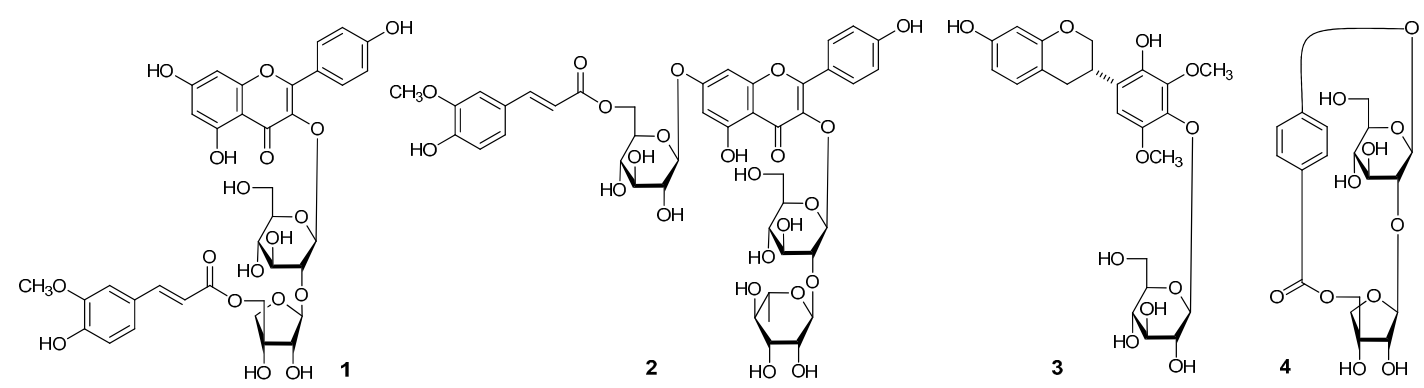

Figure 1. The new compounds 1-4 obtained from AM.
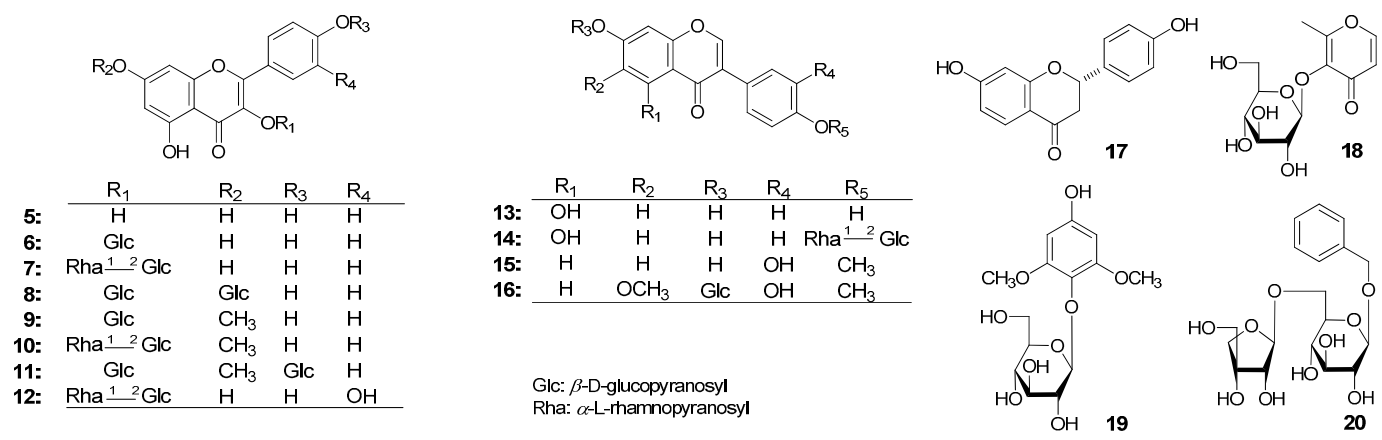

Figure 2. The known compounds 5-20 obtained from AM.

Astraflavonoid A (1) was isolated as a yellow powder with $[\alpha]_{\mathrm{D}}^{25}-69.8^{\circ}$ (in $\mathrm{MeOH}$ ). Its molecular formula is $\mathrm{C}_{36} \mathrm{H}_{36} \mathrm{O}_{18}$, as indicated by HR-Q-TOF-ESI-MS $\left(\mathrm{m} / z 755.1795[\mathrm{M}-\mathrm{H}]^{-}\right.$, calcd for $\left.\mathrm{C}_{36} \mathrm{H}_{35} \mathrm{O}_{18}, 755.1829\right)$. The IR spectrum showed absorption bands due to hydroxyl $\left(3365 \mathrm{~cm}^{-1}\right)$, $\alpha$, $\beta$-unsaturated ester carbonyl $\left(1693 \mathrm{~cm}^{-1}\right), \alpha, \beta$-unsaturated ketone $\left(1654 \mathrm{~cm}^{-1}\right)$, aromatic ring $(1604$, $1512,1453 \mathrm{~cm}^{-1}$ ), and ether functions $\left(1071 \mathrm{~cm}^{-1}\right)$. The ${ }^{1} \mathrm{H}$ - and ${ }^{13} \mathrm{C}-\mathrm{NMR}$ (DMSO- $d_{6}$, Table 1 ) spectra suggested the presence of the following moieties in 1: kaempferol aglycon [ $\delta 6.16(1 \mathrm{H}, \mathrm{d}, J=1.5 \mathrm{~Hz}$, H-6), $6.24(1 \mathrm{H}, \mathrm{d}, J=1.5 \mathrm{~Hz}, \mathrm{H}-8), 6.86\left(2 \mathrm{H}, \mathrm{d}, J=9.0 \mathrm{~Hz}, \mathrm{H}-3^{\prime}, 5^{\prime}\right), 7.99\left(2 \mathrm{H}, \mathrm{d}, J=9.0 \mathrm{~Hz}, \mathrm{H}-2^{\prime}, 6^{\prime}\right)$, $12.58\left(1 \mathrm{H}\right.$, br. s, 5-OH)], trans-p-feruloyl [ $83.81\left(3 \mathrm{H}, \mathrm{s}, 3^{\prime \prime \prime \prime}-\mathrm{OCH}_{3}\right), 6.21\left(1 \mathrm{H}, \mathrm{d}, J=16.0 \mathrm{~Hz}, \mathrm{H}-8^{\prime \prime \prime \prime}\right)$, $6.77\left(1 \mathrm{H}, \mathrm{d}, J=8.0 \mathrm{~Hz}, \mathrm{H}-5^{\prime \prime \prime \prime}\right), 6.93\left(1 \mathrm{H}, \mathrm{dd}, J=1.5,8.0 \mathrm{~Hz}, \mathrm{H}-6^{\prime \prime \prime \prime}\right), 7.14\left(1 \mathrm{H}, J=1.5 \mathrm{~Hz}, \mathrm{H}-2^{\prime \prime \prime \prime}\right), 7.25$ $\left.\left(1 \mathrm{H}, \mathrm{d}, J=16.0 \mathrm{~Hz}, \mathrm{H}-7^{\prime \prime \prime \prime}\right)\right]$, together with two anomeric proton signals [ $\delta 5.40\left(1 \mathrm{H}, \mathrm{br} . \mathrm{s}, \mathrm{H}-1^{\prime \prime \prime}\right), 5.66$ $\left.\left(1 \mathrm{H}, \mathrm{d}, J=7.5 \mathrm{~Hz}, \mathrm{H}-1^{\prime \prime}\right)\right]$. Moreover, the ${ }^{1} \mathrm{H}^{-}{ }^{1} \mathrm{H}$ COSY experiment indicated the presence of partial structure indicated in bold lines (Figure 3). In the HMBC experiment, the long-range correlations 
from the following proton to carbon pairs were observed: $\delta_{\mathrm{H}} 5.66\left(\mathrm{H}-1^{\prime \prime}\right)$ to $\delta_{\mathrm{C}} 132.7(\mathrm{C}-3) ; \delta_{\mathrm{H}} 5.40$ $\left(\mathrm{H}-1^{\prime \prime \prime}\right)$ to $\delta_{\mathrm{C}} 75.9\left(\mathrm{C}-2^{\prime \prime}\right) ; \delta_{\mathrm{H}}\left[4.15(1 \mathrm{H}, \mathrm{d}, J=11.0 \mathrm{~Hz}), 4.27(1 \mathrm{H}, \mathrm{d}, J=11.0 \mathrm{~Hz}), \mathrm{H} 2-5^{\prime \prime \prime}\right]$ to $\delta_{\mathrm{C}} 166.2$ $\left(\mathrm{C}-9^{\prime \prime \prime \prime}\right)$. Meanwhile, the ${ }^{13} \mathrm{C}-\mathrm{NMR}$ data for the sugar parts were in good agreement with those of isorhamnetin 3-O-(5-O-trans-feruloyl- $\beta$-D-apiofuranosyl)- $(1 \rightarrow 2)-\beta$-D-glucopyranoside $\left[\delta 60.5\left(\mathrm{C}-6^{\prime \prime}\right)\right.$, $68.0\left(\mathrm{C}-5^{\prime \prime \prime}\right), 70.2\left(\mathrm{C}-4^{\prime \prime}\right), 73.8\left(\mathrm{C}-4^{\prime \prime \prime}\right), 76.2\left(\mathrm{C}-2^{\prime \prime \prime}\right), 75.7\left(\mathrm{C}-2^{\prime \prime}\right), 77.0\left(\mathrm{C}-3^{\prime \prime}\right), 77.4\left(\mathrm{C}-5^{\prime \prime}\right), 77.6\left(\mathrm{C}-3^{\prime \prime \prime}\right)$, $98.5\left(\mathrm{C}-1^{\prime \prime}\right), 107.6\left(\mathrm{C}-1^{\prime \prime \prime}\right)$ ] [19]. Consequently, the structure of 1 was elucidated to be kaempferol 3-O-[(5-O-trans- $p$-feruloyl)- $\beta$-D-apiofuranosyl] $(1 \rightarrow 2)-\beta$-D-glucopyranoside.

Table 1. ${ }^{1} \mathrm{H}$ - and ${ }^{13} \mathrm{C}-\mathrm{NMR}$ data for 1 in DMSO- $d_{6}$.

\begin{tabular}{cccccc}
\hline No. & $\delta_{\mathbf{C}}$ & $\delta_{\mathbf{H}}(\boldsymbol{J}$ in Hz) & No. & $\delta_{\mathbf{C}}$ & $\delta_{\mathbf{H}}(\boldsymbol{J}$ in Hz) \\
\hline 2 & 155.4 & - & $6^{\prime \prime}$ & 60.6 & 3.29 (m, overlapped) \\
3 & 132.7 & - & & & 3.55 (br. d, ca. 12) \\
4 & 177.1 & - & $1^{\prime \prime \prime}$ & 107.7 & 5.40 (br. s) \\
5 & 161.2 & - & $2^{\prime \prime \prime}$ & 76.3 & $3.75(\mathrm{br}$ s $)$ \\
6 & 98.5 & $6.16(\mathrm{~d}, 1.5)$ & $3^{\prime \prime \prime}$ & 77.5 & - \\
7 & 163.9 & - & $4^{\prime \prime \prime}$ & 73.6 & $3.57(\mathrm{~d}, 9.5)$ \\
8 & 93.3 & $6.24(\mathrm{~d}, 1.5)$ & & & $3.95(\mathrm{~d}, 9.5)$ \\
9 & 156.0 & - & $5^{\prime \prime \prime}$ & 67.6 & $4.15(\mathrm{~d}, 11.0)$ \\
10 & 103.9 & - & & & $4.27(\mathrm{~d}, 11.0)$ \\
$1^{\prime}$ & 120.9 & - & $1^{\prime \prime \prime \prime}$ & 125.4 & - \\
$2^{\prime}, 6^{\prime}$ & 130.6 & $7.99(\mathrm{~d}, 9.0)$ & $2^{\prime \prime \prime \prime}$ & 110.7 & $7.14(\mathrm{~d}, 1.5)$ \\
$3^{\prime}, 5^{\prime}$ & 114.9 & $6.86(\mathrm{~d}, 9.0)$ & $3^{\prime \prime \prime \prime}$ & 147.7 & - \\
$4^{\prime}$ & 159.8 & - & $4^{\prime \prime \prime \prime}$ & 149.1 & - \\
$5-\mathrm{OH}$ & - & $12.58(\mathrm{br} . \mathrm{s})$ & $5^{\prime \prime \prime \prime}$ & 115.3 & $6.77(\mathrm{~d}, 8.0)$ \\
$1^{\prime \prime}$ & 98.3 & $5.66(\mathrm{~d}, 7.5)$ & $6^{\prime \prime \prime \prime}$ & 122.9 & $6.93(\mathrm{dd}, 1.5,8.0)$ \\
$2^{\prime \prime}$ & 75.9 & $3.49(\mathrm{dd}, 7.5,9.0)$ & $7^{\prime \prime \prime \prime}$ & 144.5 & $7.25(\mathrm{~d}, 16.0)$ \\
$3^{\prime \prime}$ & 76.9 & $3.42(\mathrm{dd}, 9.0,9.0)$ & $8^{\prime \prime \prime \prime}$ & 114.0 & $6.21(\mathrm{~d}, 16.0)$ \\
$4^{\prime \prime}$ & 70.2 & $3.10(\mathrm{dd}, 9.0,9.0)$ & $9^{\prime \prime \prime \prime}$ & 166.2 & - \\
$5^{\prime \prime}$ & 77.4 & $3.09(\mathrm{~m})$ & $3^{\prime \prime \prime \prime}-\mathrm{OCH}_{3}$ & 55.5 & $3.81(\mathrm{~s})$ \\
\hline
\end{tabular}

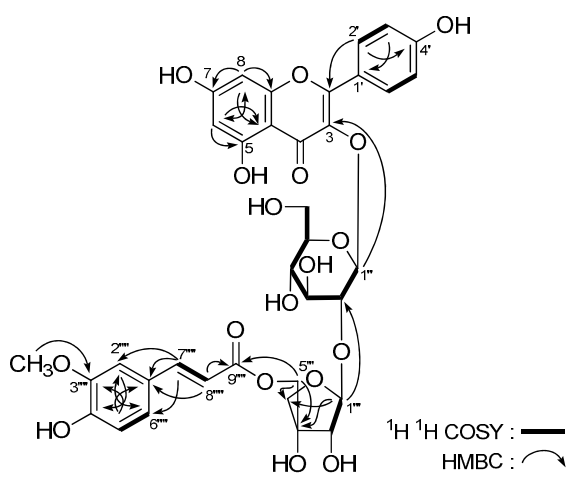

Figure 3. The main ${ }^{1} \mathrm{H}_{-}{ }^{1} \mathrm{H}$ COSY and $\mathrm{HMBC}$ correlations of $\mathbf{1}$.

Astraflavonoid B (2) displayed a negative optical rotation $\left([\alpha]_{\mathrm{D}}^{25}-91.7^{\circ}\right.$ in $\left.\mathrm{MeOH}\right)$. Its molecular formula, $\mathrm{C}_{43} \mathrm{H}_{48} \mathrm{O}_{23}$, was determined from the molecular ion peak at $m / z 931.2525[\mathrm{M}-\mathrm{H}]^{-}$ by HR-Q-TOF-ESI-MS measurement. Acid hydrolysis of 2 with $1 \mathrm{M} \mathrm{HCl}$ yielded D-glucose and L-rhamnose, which were identified on the basis of their retention times (HPLC) and optical rotations [20] The ${ }^{1} \mathrm{H}-,{ }^{13} \mathrm{C}-\mathrm{NMR}\left(\mathrm{DMSO}-d_{6}\right.$, Table 2) and various $2 \mathrm{D}$ NMR spectra indicated the presence of a kaempferol aglycon $[\delta 6.51(1 \mathrm{H}, \mathrm{d}, J=1.5 \mathrm{~Hz}, \mathrm{H}-6), 6.81(1 \mathrm{H}, \mathrm{d}, J=1.5 \mathrm{~Hz}, \mathrm{H}-8), 6.87$ $\left.\left(2 \mathrm{H}, \mathrm{d}, J=9.0 \mathrm{~Hz}, \mathrm{H}-3^{\prime}, 5^{\prime}\right), 8.06\left(2 \mathrm{H}, \mathrm{d}, J=9.0 \mathrm{~Hz}, \mathrm{H}-2^{\prime}, 6^{\prime}\right), 12.63(1 \mathrm{H}, \mathrm{br} . \mathrm{s}, 5-\mathrm{OH})\right]$, trans-p-feruloyl

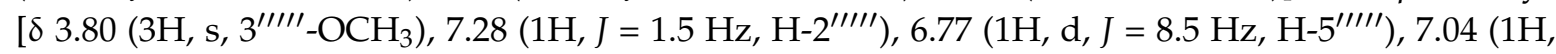
$\left.\left.\mathrm{dd}, J=1.5,8.5 \mathrm{~Hz}, \mathrm{H}-6^{\prime \prime \prime \prime \prime}\right), 7.54\left(1 \mathrm{H}, \mathrm{d}, J=16.0 \mathrm{~Hz}, \mathrm{H}-7^{\prime \prime \prime \prime \prime}\right), 6.46\left(1 \mathrm{H}, \mathrm{d}, J=16.0 \mathrm{~Hz}, \mathrm{H}-8^{\prime \prime \prime \prime \prime}\right)\right]$, along with two $\beta$-D-glucopyranosyl [ $\left.\delta 5.18\left(1 \mathrm{H}, \mathrm{d}, J=7.0 \mathrm{~Hz}, \mathrm{H}-1^{\prime \prime \prime \prime}\right), 5.67\left(1 \mathrm{H}, \mathrm{d}, J=7.5 \mathrm{~Hz}, \mathrm{H}-1^{\prime \prime}\right)\right]$ 
and one $\alpha$-L-rhamnopyranosyl [ $\left.\delta 0.79\left(3 \mathrm{H}, \mathrm{d}, J=6.0 \mathrm{~Hz}, 6^{\prime \prime \prime}-\mathrm{CH}_{3}\right), 5.10\left(1 \mathrm{H}, \mathrm{br} . \mathrm{s}, \mathrm{H}-1^{\prime \prime \prime}\right)\right]$ moiety. Furthermore, according to the long-range correlations (Figure 4) observed from HMBC spectrum, the indicated locations of the trans-p-feruloyl, and sugar moieties in $\mathbf{2}$ could be determined.

Table 2. ${ }^{1} \mathrm{H}$ - and ${ }^{13} \mathrm{C}-\mathrm{NMR}$ data for 2 in DMSO- $d_{6}$.

\begin{tabular}{|c|c|c|c|c|c|}
\hline No. & $\delta_{C}$ & $\delta_{H}(J$ in $\mathrm{Hz})$ & No. & $\delta_{C}$ & $\delta_{\mathrm{H}}(J$ in $\mathrm{Hz})$ \\
\hline 2 & 155.8 & - & $2^{\prime \prime \prime}$ & 70.5 & 3.75 (br. s) \\
\hline 3 & 132.9 & - & $3^{\prime \prime \prime}$ & 70.4 & $3.46(\mathrm{dd}, 3.0,9.0)$ \\
\hline 4 & 177.4 & - & $4^{\prime \prime \prime}$ & 71.8 & $3.14(\mathrm{dd}, 9.0,9.0)$ \\
\hline 5 & 160.9 & - & $5^{\prime \prime \prime}$ & 68.2 & $3.72(\mathrm{~m})$ \\
\hline 6 & 99.6 & $6.51(d, 1.5)$ & 'II & 17.2 & $0.79(\mathrm{~d}, 6.0)$ \\
\hline 7 & 162.6 & - & $1^{\prime \prime \prime \prime \prime}$ & 99.1 & $5.18(\mathrm{~d}, 7.0)$ \\
\hline 8 & 94.4 & $6.81(\mathrm{~d}, 1.5)$ & $2^{\prime \prime \prime \prime \prime}$ & 73.0 & $3.32(\mathrm{dd}, 7.0,9.0)$ \\
\hline 9 & 156.6 & - & $3^{\prime \prime \prime \prime}$ & 76.1 & $3.36(\mathrm{dd}, 9.0,9.0)$ \\
\hline 10 & 105.6 & - & $4^{\prime \prime \prime \prime}$ & 69.3 & 3.31 (m, overlapped) \\
\hline $1^{\prime}$ & 120.6 & - & $5^{\prime \prime \prime \prime}$ & 73.8 & $3.80(\mathrm{~m})$ \\
\hline $2^{\prime}, 6^{\prime}$ & 130.7 & $8.06(d, 9.0)$ & $6^{\prime \prime \prime \prime}$ & 63.0 & $4.20(\mathrm{dd}, 5.5,12.0)$ \\
\hline $3^{\prime}, 5^{\prime}$ & 115.0 & $6.87(\mathrm{~d}, 9.0)$ & & & 4.44 (br. d, ca. 12) \\
\hline $4^{\prime}$ & 160.0 & - & $1^{\prime \prime \prime \prime \prime \prime}$ & 125.4 & - \\
\hline $5-\mathrm{OH}$ & - & 12.63 (br. s) & $2^{\prime \prime \prime \prime \prime \prime}$ & 110.9 & $7.28(\mathrm{~d}, 1.5)$ \\
\hline $1^{\prime \prime}$ & 98.2 & $5.67(\mathrm{~d}, 7.5)$ & $3^{\prime \prime \prime \prime \prime \prime}$ & 147.8 & - \\
\hline $2^{\prime \prime}$ & 77.5 & $3.46(\mathrm{dd}, 7.5,9.0)$ & $4^{\prime \prime \prime \prime \prime}$ & 149.3 & - \\
\hline $3^{\prime \prime}$ & 77.2 & $3.40(\mathrm{dd}, 9.0,9.0)$ & $5^{\prime \prime \prime \prime \prime \prime}$ & 115.4 & $6.77(\mathrm{~d}, 8.5)$ \\
\hline $4^{\prime \prime}$ & 70.1 & $3.09(\mathrm{dd}, 9.0,9.0)$ & $6^{\prime \prime \prime \prime \prime \prime}$ & 123.1 & $7.04(\mathrm{dd}, 1.5,8.5)$ \\
\hline $5^{\prime \prime}$ & 77.4 & $3.09(\mathrm{~m})$ & $7^{\prime \prime \prime \prime \prime \prime}$ & 145.2 & $7.54(\mathrm{~d}, 16.0)$ \\
\hline \multirow[t]{2}{*}{$6^{\prime \prime}$} & 60.7 & $3.28(\mathrm{dd}, 4.5,11.5)$ & $8^{\prime \prime \prime \prime \prime \prime}$ & 114.0 & $6.46(\mathrm{~d}, 16.0)$ \\
\hline & & 3.56 (br. d, ca. 12) & $9^{\prime \prime \prime \prime \prime \prime}$ & 166.5 & - \\
\hline $1^{\prime \prime \prime}$ & 100.5 & 5.10 (br. s) & $3^{\prime \prime \prime \prime \prime \prime}-\mathrm{OCH}_{3}$ & 55.6 & $3.80(\mathrm{~s})$ \\
\hline
\end{tabular}

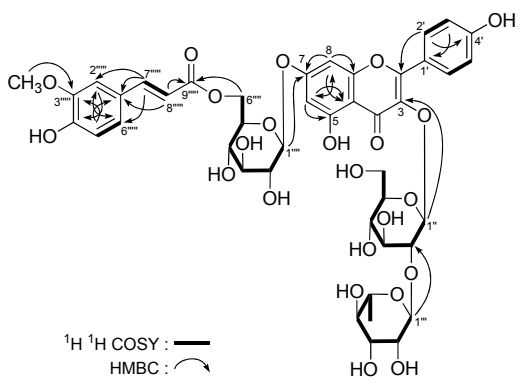

Figure 4. The main ${ }^{1} \mathrm{H}_{-}{ }^{1} \mathrm{H}$ COSY and $\mathrm{HMBC}$ correlations of 2.

Astraflavonoid C (3) was obtained as a white powder with negative optical rotation $\left([\alpha]_{\mathrm{D}}^{25}-26.7^{\circ}\right.$ in $\mathrm{MeOH})$. Its molecular formula, $\mathrm{C}_{23} \mathrm{H}_{28} \mathrm{O}_{11}$, was established by HR-Q-TOF-ESI-MS $(\mathrm{m} / z 479.1578$ [M $-\mathrm{H}]^{-}$; calcd for $\mathrm{C}_{23} \mathrm{H}_{27} \mathrm{O}_{11}, 479.1559$ ). Its acid hydrolysis yielded D-glucose [21]. The ${ }^{1} \mathrm{H}-$, ${ }^{13} \mathrm{C}-\mathrm{NMR}\left(\mathrm{CD}_{3} \mathrm{OD}\right.$, Table 3) and DEPT spectra suggested the presence of one ABX-type aromatic ring, one pentasubstituted aromatic ring, one $\beta$-D-glucopyranosyl, and one oxygenated methylene, together with one methylene, one methane, and two methoxy groups. The ${ }^{1} \mathrm{H}-{ }^{1} \mathrm{H} C O S Y$ experiment indicated the presence of the partial structure indicated in bold lines (Figure 5). On the other hand, the long-range correlations from $\mathrm{H}_{2}-2$ to $\mathrm{C}-9, \mathrm{C}-1^{\prime} ; \mathrm{H}_{2}-4$ to $\mathrm{C}-5, \mathrm{C}-9, \mathrm{C}-10, \mathrm{C}-1^{\prime} ; \mathrm{H}-5$ to $\mathrm{C}-4, \mathrm{C}-7, \mathrm{C}-9 ; \mathrm{H}-6$ to $\mathrm{C}-7, \mathrm{C}-8, \mathrm{C}-10 ; \mathrm{H}-8$ to $\mathrm{C}-6, \mathrm{C}-7, \mathrm{C}-10 ; \mathrm{H}-6^{\prime}$ to $\mathrm{C}-3, \mathrm{C}-2^{\prime}, \mathrm{C}^{\prime} 4^{\prime}, \mathrm{C}^{\prime} 5^{\prime} ; 3^{\prime}-\mathrm{OCH}_{3}$ to $\mathrm{C}-3^{\prime} ; 5^{\prime}-\mathrm{OCH}_{3}$ to $\mathrm{C}-5^{\prime}$; $\mathrm{H}-1^{\prime \prime}$ to $\mathrm{C}-4^{\prime}$ were clearly found in the HMBC spectra. Furthermore, the NOE correlations between $\delta_{\mathrm{H}} 4.85\left(\mathrm{H}-1^{\prime \prime}\right)$ and $\delta_{\mathrm{H}} 3.83\left(5^{\prime}-\mathrm{OCH}_{3}\right), 3.90\left(3^{\prime}-\mathrm{OCH}_{3}\right)$ observed in the NOESY spectrum confirmed the substituted positions of two methoxy groups and the $\beta$-D-glucopyranosyl unit. Thus, the planar structure of $\mathbf{3}$ was identified as that of isoflavan glycoside. Finally, the CD spectrum of $\mathbf{3}$ displayed 
negative Cotton effect at $285 \mathrm{~nm}(\Delta \varepsilon:-11.84)$, which indicated the absolute configuration of 3-position was $S[20]$.

Table 3. ${ }^{1} \mathrm{H}$ - and ${ }^{13} \mathrm{C}-\mathrm{NMR}$ data for 3 in $\mathrm{CD}_{3} \mathrm{OD}$.

\begin{tabular}{cccccc}
\hline No. & $\boldsymbol{\delta}_{\mathbf{C}}$ & $\boldsymbol{\delta}_{\mathbf{H}}(\boldsymbol{J}$ in $\mathbf{H z})$ & No. & $\boldsymbol{\delta}_{\mathbf{C}}$ & $\boldsymbol{\delta}_{\mathbf{H}}(\boldsymbol{J}$ in $\mathbf{H z})$ \\
\hline 2 & 71.6 & $3.84(\mathrm{dd}, 8.5,9.0)$ & $4^{\prime}$ & 141.3 & - \\
& & $4.33(\mathrm{dd}, 2.0,9.0)$ & $5^{\prime}$ & 141.6 & - \\
3 & 32.4 & $3.80(\mathrm{~m})$ & $6^{\prime}$ & 109.8 & $6.42(\mathrm{~s})$ \\
4 & 32.5 & $2.75(\mathrm{~m})$ & $1^{\prime \prime}$ & 105.6 & $4.85(\mathrm{~d}, 9.0)$ \\
5 & 131.3 & $6.85(\mathrm{~d}, 8.0)$ & $2^{\prime \prime}$ & 75.6 & $3.43(\mathrm{~m}$, overlapped $)$ \\
6 & 109.2 & $6.32(\mathrm{dd}, 2.5,8.0)$ & $3^{\prime \prime}$ & 77.9 & $3.43(\mathrm{~m}$, overlapped $)$ \\
7 & 157.6 & - & $4^{\prime \prime}$ & 71.5 & $3.36(\mathrm{dd}, 6.5,9.5)$ \\
8 & 103.9 & $6.25(\mathrm{~d}, 2.5)$ & $5^{\prime \prime}$ & 78.2 & $3.24(\mathrm{~m})$ \\
9 & 156.3 & - & $6^{\prime \prime}$ & 62.8 & $3.70(\mathrm{dd}, 5.0,11.5)$ \\
10 & 114.9 & - & & & $3.85(\mathrm{dd}, 2.0,11.5)$ \\
$1^{\prime}$ & 133.1 & - & $3^{\prime}-\mathrm{OCH}_{3}$ & 61.9 & $3.90(\mathrm{~s})$ \\
$2^{\prime}$ & 148.8 & - & $5^{\prime}-\mathrm{OCH}_{3}$ & 61.3 & $3.83(\mathrm{~s})$ \\
$3^{\prime}$ & 147.6 & - & & \\
\hline
\end{tabular}
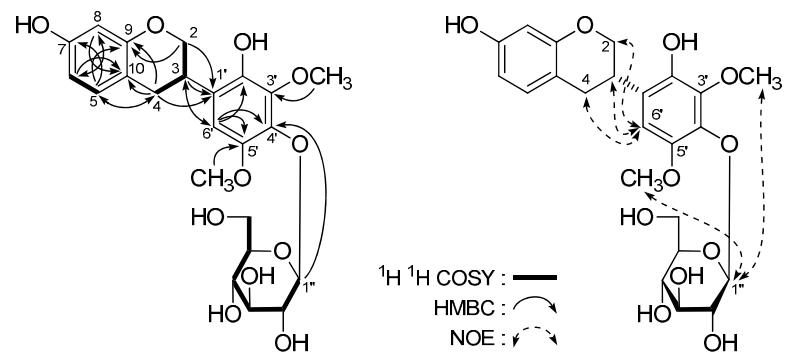

Figure 5. The main ${ }^{1} \mathrm{H}_{-}{ }^{1} \mathrm{H}$ COSY, HMBC, and NOE correlations of 3.

Astramemoside A (4) was a white powder. Its molecular formula was deduced as $\mathrm{C}_{18} \mathrm{H}_{22} \mathrm{O}_{11}$ from the $[\mathrm{M}-\mathrm{H}]^{-}$quasi-molecular ion at $m / z 413.1082$ (calcd for $\mathrm{C}_{18} \mathrm{H}_{21} \mathrm{O}_{11}, 413.1089$ ) in the negative-ion HRESI-TOF-MS spectrum. The IR spectrum showed absorption bands due to hydroxyl $\left(3373 \mathrm{~cm}^{-1}\right)$, ester carbonyl $\left(1721 \mathrm{~cm}^{-1}\right)$, aromatic ring $\left(1609,1511,1451 \mathrm{~cm}^{-1}\right)$, and ether $\left(1081 \mathrm{~cm}^{-1}\right)$ functions. The ${ }^{1} \mathrm{H}-,{ }^{13} \mathrm{C}-\mathrm{NMR}$ (DMSO- $d_{6}$, Table 4 ) and various 2D NMR spectra (Figure 6) suggested the presence of a $p$-hydroxybenzoic acid unit $\left[\delta_{\mathrm{H}} 6.97(2 \mathrm{H}, \mathrm{d}, J=9.0 \mathrm{~Hz}, \mathrm{H}-3,5), 7.53(2 \mathrm{H}, \mathrm{d}, J=9.0 \mathrm{~Hz}, \mathrm{H}-2,6)\right.$, $\left.\delta_{\mathrm{C}} 114.8(\mathrm{C}-3,5), 122.3(\mathrm{C}-1), 130.9(\mathrm{C}-2,6), 160.2(\mathrm{C}-4), 164.6(\mathrm{C}-7)\right]$.

Table 4. ${ }^{1} \mathrm{H}$ - and ${ }^{13} \mathrm{C}-\mathrm{NMR}$ data for 4 in DMSO- $d_{6}$.

\begin{tabular}{|c|c|c|c|c|c|}
\hline No. & $\delta_{C}$ & $\delta_{H}(J$ in $\mathbf{H z})$ & No. & $\delta_{C}$ & $\delta_{H}(J$ in $\mathbf{H z})$ \\
\hline 1 & 122.3 & - & $6^{\prime}$ & 60.2 & $3.45(\mathrm{dd}, 5.5,12.0)$ \\
\hline 2,6 & 130.9 & $7.53(\mathrm{~d}, 9.0)$ & & & 3.65 (br. d, ca. 12) \\
\hline 3,5 & 114.8 & $6.97(\mathrm{~d}, 9.0)$ & $1^{\prime \prime}$ & 107.7 & 5.34 (br. s) \\
\hline 4 & 160.2 & - & $2^{\prime \prime}$ & 76.3 & 3.65 (br. s) \\
\hline 7 & 164.6 & - & $3^{\prime \prime}$ & 77.5 & - \\
\hline $1^{\prime}$ & 96.8 & $5.18(\mathrm{~d}, 7.0)$ & $4^{\prime \prime}$ & 73.4 & $3.80(\mathrm{~d}, 9.5)$ \\
\hline $2^{\prime}$ & 75.3 & $3.53(\mathrm{dd}, 7.0,9.0)$ & & & $4.31(\mathrm{~d}, 9.5)$ \\
\hline $3^{\prime}$ & 76.7 & $3.52(\mathrm{dd}, 9.0,9.0)$ & $5^{\prime \prime}$ & 68.0 & $3.87(\mathrm{~d}, 11.0)$ \\
\hline $4^{\prime}$ & 69.5 & $3.20(\mathrm{dd}, 9.0,9.0)$ & & & $4.32(\mathrm{~d}, 11.0)$ \\
\hline $5^{\prime}$ & 76.7 & $3.52(\mathrm{~m})$ & & & \\
\hline
\end{tabular}




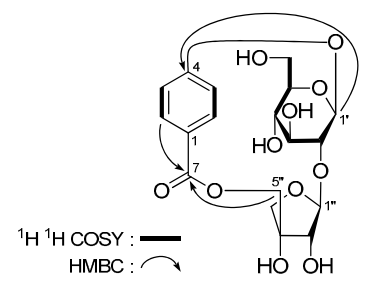

Figure 6. The main ${ }^{1} \mathrm{H}_{-}{ }^{1} \mathrm{H}$ COSY and $\mathrm{HMBC}$ correlations of 4.

Comparison of the ${ }^{1} \mathrm{H}$ - and ${ }^{13} \mathrm{C}-\mathrm{NMR}$ spectroscopic data of $\mathbf{4}$ with those of $\mathbf{1}$ identified the sugar moiety to be $\beta$-D-apiofuranosyl $(1 \rightarrow 2)-\beta$-D-glucopyranose. Moreover, the 5 -position of the $\beta$-D-apiofuranosyl moiety was substituted too. Meanwhile, the long-range correlations from $\mathrm{H}-2,6$ to $\mathrm{C}-4, \mathrm{C}-7 ; \mathrm{H}-1^{\prime}$ to $\mathrm{C}-4 ; \mathrm{H}-1^{\prime \prime}$ to $\mathrm{C}-2^{\prime} ; \mathrm{H}_{2}-5^{\prime \prime}$ to $\mathrm{C}-7$ observed in the HMBC experiment further proved the correctness of the above deductions.

The effects of the compounds obtained from AM on glucose consumption were analyzed in differentiated L6 myotubes in vitro. To create the assay method, standardization of basic parameters like differentiation time, the number of cells to seed, amount of D-glucose to be used and time of incubation were determined (data not shown). As shown in Figure 7, insulin increased the glucose consumption in L6 myotubes to about $4.76 \pm 0.33 \mu \mathrm{g} /$ well $(p<0.001)$ and the percentage of the raise reached about $9.01 \%$, which serves as a positive control for our study. Among the tested compounds, $1,2,3,7,8,10,11,14,15$ and 18 possessed significant promoting effects on glucose consumption in L6 myotubes, the glucose consumption of which were $5.02 \pm 0.29,4.92 \pm 0.36,3.20 \pm 0.58,4.86 \pm 0.67$, $3.37 \pm 0.62,3.04 \pm 0.86,2.94 \pm 0.60,3.96 \pm 1.21,2.44 \pm 0.59$ and $3.15 \pm 1.00 \mu \mathrm{g} /$ well, respectively. At the concentration of $30 \mu \mathrm{mol} / \mathrm{L}$, compounds 1, 2 and 7 led to $9.67 \%, 9.48 \%$ and $9.33 \%$ increments in glucose consumption, respectively, which was comparable to the effects of insulin. However, the other isolates showed no obvious effect on glucose consumption. These results indicated that some of the constituents in AM can stimulate glucose consumption in L6 myotubes to various degrees.

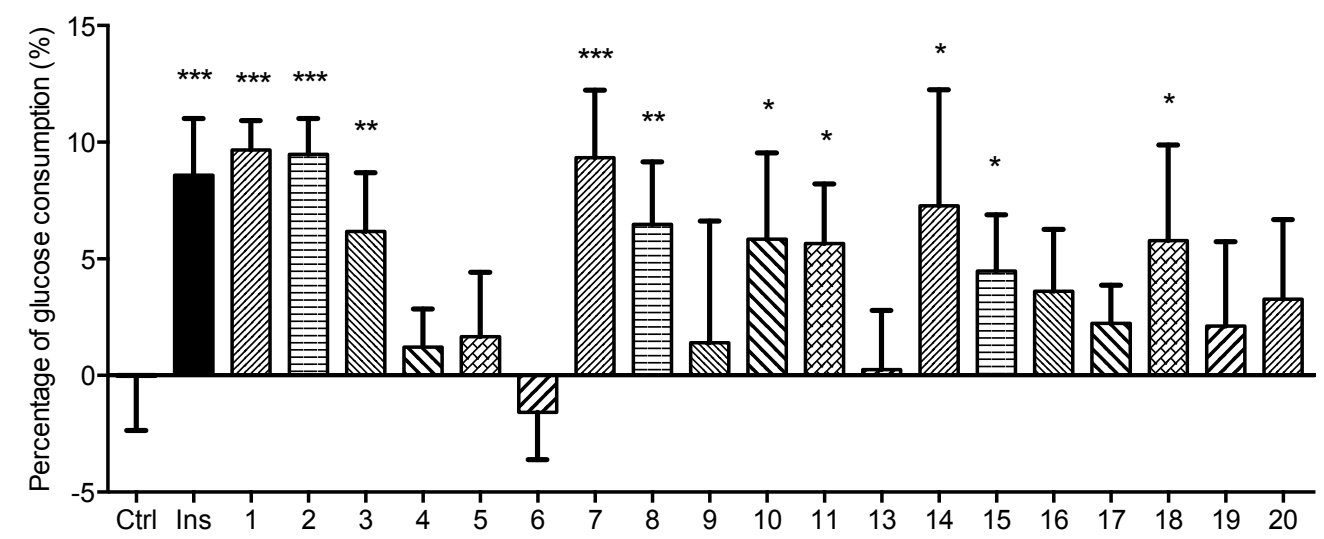

Figure 7. Effects of compounds 1-11 and 13-20 on glucose consumption in L6 myotubes. L6 myoblasts $\left(1 \times 10^{4}\right.$ cells/well) were subcultured into 48-place multiwell plates in $2 \%$ FBS/DMEM for 7 days to form myotubes. The differentiated myotubes were kept in HBS with no serum or glucose for $2 \mathrm{~h}$, and then were continue incubated in HBS containing $1 \mathrm{mg} / \mathrm{mL}$ D-glucose and $2 \%$ FBS with or without insulin (Ins, $2 \mu \mathrm{mol} / \mathrm{L})$ or obtained compounds $(30 \mu \mathrm{mol} / \mathrm{L})$ for another $4 \mathrm{~h}$. Then the glucose concentrations in the supernatant were detected using glucose assay kit and the percentage of glucose consumption in each well was calculated to express the results. Each value represents the mean \pm S.E.M., $n=6 .{ }^{* *} p<0.001,{ }^{* *} p<0.01,{ }^{*} p<0.05$ vs. control group (Ctrl).

On the basis of the activity results of kaempferol and its glycosides, we can deduce that the glucosylation of 3-hydroxyl group would increase the effect on glucose consumption in L-6 cells, and 
disaccharide substitution at 3-hydroxyl showed a stronger activity than monosaccharide substitution. Due to the limited number of compounds, detailed studies are in progress to evaluate more kaempferol glycosides to clarify these structure-activity relationships.

\section{Experimental Section}

\subsection{General Information}

The following instruments were used to obtain physical data: optical rotations were recorded on an Autopol IV automatic polarimeter ( $l=50 \mathrm{~mm}$; Rudolph Research Analytical, Hackettstown, NJ, USA). IR and UV spectra were determined on 640-IR FT-IR (Varian Australia Pty Ltd., Mulgrave, Australia) and Cary 50 UV-Vis spectrophotometers, respectively (Varian, Inc., Hubbardsdon, MA, USA). ${ }^{1} \mathrm{H}-$ and ${ }^{13} \mathrm{C}-\mathrm{NMR}$ spectra were measured on a Bruker $500 \mathrm{MHz}$ NMR spectrometer at $500 \mathrm{MHz}$ for ${ }^{1} \mathrm{H}-$ and $125 \mathrm{MHz}$ for ${ }^{13} \mathrm{C}-\mathrm{NMR}$ (Bruker BioSpin AG Industriestrasse $26 \mathrm{CH}-8117$, Fällanden, Switzerland). Negative-ion HR-ESI-Q-TOF-MS were recorded on an Aglient 6520 Q-TOF mass spectrometer (Agilent Corp., Santa Clara, CA, USA).

The following supports were used for chromatography: a macroporous synthetic resin (D101)

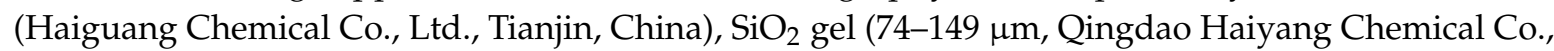
Ltd., Qingdao, China), and ODS (50 $\mu \mathrm{m}$, YMC Co., Ltd., Tokyo, Japan). Prep HPLC was performed on an ODS column (Cosmosil 5C18-MS-II, Tokyo, Japan; $\Phi=20 \mathrm{~mm}, l=250 \mathrm{~mm}$, flow rate $9.0 \mathrm{~mL} / \mathrm{min}$ ), and the eluate was monitored with a UV detector (Shimadzu RID-10 ${ }^{\mathrm{a}}$ UV-vis, Shimadzu Co. Ltd., Kyoto, Japan).

\subsection{Plant Material}

The stems of Astragalus membranaceus (Fisch.) Bge. var. mongholicus (Bge.) Hsiao. were collected from Gansu Province, China, and identified by Dr. Li Tianxiang (Experiment Teaching Department, Tianjin University of Traditional Chinese Medicine, Tianjin, China). The voucher specimen was deposited at the Academy of Traditional Chinese Medicine of Tianjin University of TCM.

\subsection{Extraction and Isolation}

The stems of AM were dealt with by the method described before [1] to give the 95\% $\mathrm{EtOH}$ eluate from D101 macroporous resin CC. The 95\% EtOH eluate (90.6 g) was subjected to $\mathrm{SiO}_{2}$ gel CC to yield fourteen fractions (Fr. 1-14). Fraction 2 (0.16 g) was purified by Prep HPLC $\left[\mathrm{MeOH}-\mathrm{H}_{2} \mathrm{O}(55: 45, v / v)\right]$ to afford calycosin $(15,13.2 \mathrm{mg})$. Using the same isolation conditions as fraction 2, kaempferol $(5,8.7 \mathrm{mg})$, genistein $(\mathbf{1 3}, 7.2 \mathrm{mg})$, and (-)-liquiritigenin $(\mathbf{1 7}, 8.8 \mathrm{mg})$ were obtained from fraction $3(0.78 \mathrm{~g})$. Fraction $6(7.0 \mathrm{~g})$ was isolated by ODS CC, and purified by Prep HPLC to yield astraflavonoid C (3, $25.0 \mathrm{mg})$, kaempferol-3-O- $\beta$-D-glucoside $(6,43.8 \mathrm{mg})$, rhamnocitrin-3-O- $\beta$-D-glucopyranoside $(9,52.5 \mathrm{mg})$, and odoratin-7-O- $\beta$-D-glucopyranoside $(16,14.4 \mathrm{mg})$. Fraction $7(6.9 \mathrm{~g})$ was subjected to $\mathrm{SiO}_{2}$ gel, ODS, Sephadex LH-20 CC and Prep HPLC to furnish astraflavonoid A (1, $8.5 \mathrm{mg})$, maltol- $\beta$-D-glucopyranoside $(\mathbf{1 8}, 59.0 \mathrm{mg})$, and 2,6-dimethoxy-4-hydroxyphenyl-1-O- $\beta$-D-glucopyranoside (19, $12.2 \mathrm{mg})$. Fraction 8 (7.4 g) was subjected to ODS and Sephadex LH-20 CC, along with Prep HPLC to afford benzyl- $\alpha-$ L-arabinopyranosyl $\left(1^{\prime \prime} \rightarrow 6^{\prime}\right)$ - $\beta$-D-glucopyranoside $(20,46.4 \mathrm{mg})$. Fraction 9 (7.0 g) was subjected to ODS CC, and purified by Prep HPLC to give rhamnocitrin-3-O-neohesperoside (10, $46.3 \mathrm{mg})$ and sophorabioside (14, $38.1 \mathrm{mg})$. Fraction $10(12.0 \mathrm{~g})$ was isolated by Sephadex LH-20 CC and Prep HPLC to yield complanatuside (11, $12.4 \mathrm{mg})$. Fraction 12 (8.2 g) was separated by Prep HPLC to provide astraflavonoid B (2, $22.2 \mathrm{mg})$, astramemoside A (4, 6.7 mg), kaempferol-3-O-(2-O- $\alpha$-L-rhamnopyranosyl)- $\beta$-D-glucopyranoside $(7,14.5$. mg) and kaempferol-3,7di-O- $\beta$-D-glucopyranoside (8, $11.2 \mathrm{mg})$. Fraction 13 (12.1 g) was subjected to Sephadex LH-20 CC and further purified by Prep HPLC to afford quercetin-3-O- $\beta$-D-neospheroside (12, $2.2 \mathrm{mg})$. 


\subsection{Compound Characterization}

Astraflavonoid $A(\mathbf{1})$ : Yellow powder; $[\alpha]_{\mathrm{D}}^{25}-69.8^{\circ}(c=0.61, \mathrm{MeOH}) ; \mathrm{UV}(\mathrm{MeOH}) \lambda_{\max }(\log \varepsilon) 268$ (3.99), 292 (3.94, sh), 329 (4.06); IR (KBr) $\nu_{\max }$ 3365, 2926, 2855, 1693, 1654, 1604, 1512, 1453, 1361, 1275, $1178,1123,1071,1026,839 \mathrm{~cm}^{-1} ;{ }^{1} \mathrm{H}$ - and ${ }^{13} \mathrm{C}-\mathrm{NMR}$ (DMSO- $d_{6}$ ) data see Table 1 ; Negative-ion mode HR-Q-TOF-ESI-MS m/z $755.1795[\mathrm{M}-\mathrm{H}]^{-}$(calcd for $\mathrm{C}_{36} \mathrm{H}_{35} \mathrm{O}_{18}$, 755.1829).

Astraflavonoid B (2): Yellow powder; $[\alpha]_{\mathrm{D}}^{25}-91.7^{\circ}(c=0.87, \mathrm{MeOH}) ; \mathrm{UV}(\mathrm{MeOH}) \lambda_{\max }(\log \varepsilon) 267$ (4.19), 292 (4.08, sh), 325 (4.20); IR (KBr) $v_{\max }$ 3365, 2926, 1698, 1652, 1599, 1512, 1453, 1346, 1275, $1210,1179,1124,1071,840 \mathrm{~cm}^{-1} ;{ }^{1} \mathrm{H}$ - and ${ }^{13} \mathrm{C}-\mathrm{NMR}$ (DMSO- $d_{6}$ ) data see Table 2; Negative-ion mode HR-Q-TOF-ESI-MS m/z 931.2525 [M - H] ${ }^{-}$(calcd for $\mathrm{C}_{43} \mathrm{H}_{47} \mathrm{O}_{23}$, 931.2514).

Astraflavonoid C (3): White powder; $[\alpha]_{\mathrm{D}}^{25}-26.7^{\circ}(c=0.89, \mathrm{MeOH}) ; \mathrm{CD}(c=0.0021 \mathrm{M}, \mathrm{MeOH}) \Delta \varepsilon(\lambda \mathrm{nm})$ - 11.84 (285); UV (MeOH) $\lambda_{\max }(\log \varepsilon) 228$ (4.07, sh), 284 (3.68); IR (KBr) $\nu_{\max } 3367,2938,2848,1622$, 1595, 1508, 1461, 1367, 1156, 1109, 1071, 1024, $847 \mathrm{~cm}^{-1} ;{ }^{1} \mathrm{H}-$ and ${ }^{13} \mathrm{C}-\mathrm{NMR}\left(\mathrm{CD}_{3} \mathrm{OD}\right)$ data see Table 3; Negative-ion mode HR-Q-TOF-ESI-MS $m / z 479.1578[\mathrm{M}-\mathrm{H}]^{-}$(calcd for $\mathrm{C}_{23} \mathrm{H}_{27} \mathrm{O}_{11}$, 479.1559).

Astramemoside A (4): White powder; $[\alpha]_{\mathrm{D}}^{25}-21.0^{\circ}(c=0.39, \mathrm{MeOH}) ; \mathrm{UV}(\mathrm{MeOH}) \lambda_{\max }(\log \varepsilon) 249(3.41)$; IR $(\mathrm{KBr}) v_{\max } 3373,2924,2889,1721,1609,1511,1451,1401,1374,1270,1242,1184,1081,1003,848$ $\mathrm{cm}^{-1} ;{ }^{1} \mathrm{H}$ - and ${ }^{13} \mathrm{C}-\mathrm{NMR}\left(\mathrm{DMSO}-d_{6}\right.$ ) data see Table 4; Negative-ion mode HR-Q-TOF-ESI-MS $m / z$ 413.1082 [M - H] $]^{-}$(calcd for $\mathrm{C}_{18} \mathrm{H}_{21} \mathrm{O}_{11}, 413.1089$ ).

\subsection{Acid Hydrolysis of 2 and 3}

A solution of compounds 2 and 3 (each $1.5 \mathrm{mg}$ ) was treated with $\mathrm{HCl}$ using the same method and conditions as reported in [21]. Identification of L-rhamnose (i) from 2; and D-glucose (ii) from 2 and 3 by comparison of its retention time and optical rotation with those of authentic sample, $t_{\mathrm{R}}$ : (i) $7.5 \mathrm{~min}$ (L-rhamnose, negative optical rotation); and (ii) $14.1 \mathrm{~min}$ (D-glucose, positive optical rotation).

\subsection{Glucose Consumption Assay of Compounds Obtained from AM}

\subsubsection{Materials}

L6 rat skeletal myoblasts cell line (Cell Resource Center, IBMS, CAMS/PUMC, Beijing, China), Dulbecco's modified Eagle's medium (DMEM, Thermo Scientific, Logan, UT, USA), fetal bovine serum (FBS, Thermo Scientific), streptomycin and penicillin G (Thermo Scientific), glucose assay kit (BioSino Bio-technology and Science Inc., Beijing, China), insulin (Sigma, St. Louis, MO, USA), D-glucose (Solarbio Bio-technology and Science Inc., Beijing, China China).

\subsubsection{Cell Culture and Differentiation}

Stock cultures of L6 myoblasts were grown in 10\% $(v / v)$ FBS/DMEM supplemented with streptomycin $(100 \mu \mathrm{g} / \mathrm{mL})$ and penicillin $\mathrm{G}(100 \mathrm{U} / \mathrm{mL})$ at $37^{\circ} \mathrm{C}$ under $5 \% \mathrm{CO}_{2}$ atmosphere and maintained below 70\% confluence. For differentiation into L6 myotubes, cells were cultured at a density of $1 \times 10^{4}$ cells/well on 48-place multiwell plates (Costar, Washington, DC, USA) and the medium was switched to $2 \%(v / v)$ FBS/DMEM for 7 days, with medium changes every second day prior to use in our experiments.

\subsubsection{Determination of Glucose Consumption in L6 Myotubes}

This method was based on some literatures [22-24] with slight modifications. Briefly, the 7-day-old myotubes were serum and glucose-deprived kept in HEPES-buffered saline (HBS, 20 mmol/L HEPES, $2 \mathrm{mmol} / \mathrm{L}$ sodium pyruvate, $136 \mathrm{mmol} / \mathrm{L} \mathrm{NaCl}, 2.7 \mathrm{mmol} / \mathrm{L} \mathrm{KCl}, 2 \mathrm{mmol} / \mathrm{L} \mathrm{KH}_{2} \mathrm{PO}_{4}, 10 \mathrm{mmol} / \mathrm{L}$ $\mathrm{Na}_{2} \mathrm{HPO}_{4}, 2.5 \mathrm{mmol} / \mathrm{L} \mathrm{MgSO}_{4}$, and $1 \mathrm{mmol} / \mathrm{L} \mathrm{CaCl}_{2}, \mathrm{pH} 7.4$ ) for $2 \mathrm{~h}$, and were thereafter incubated in HBS containing $1 \mathrm{mg} / \mathrm{mL}$ D-glucose and 2\% FBS with or without insulin (Ins, $2 \mu \mathrm{mol} / \mathrm{L}$ ) or obtained compounds (1-11, 13-20, $30 \mu \mathrm{mol} / \mathrm{L}$ each) for another $4 \mathrm{~h}$. Then glucose concentrations 
in the supernatant were determined using glucose assay kit (GOD-POD colorimetric method) and the ratio of glucose consumption in each well was calculated for further comparison. Results were expressed as a percentage of glucose consumption:

Percentage of glucose consumption $(\%)=[$ (glucose surplus of control - glucose surplus of sample)/glucose surplus of control] $\times 100 \%$

\section{Conclusions}

In summary, four new aromatic constituents, astraflavonoids $\mathrm{A}-\mathrm{C}(\mathbf{1}-\mathbf{3})$, and astramemoside $\mathrm{A}$ (4), along with sixteen known ones 5-20 were obtained from the 70\% EtOH extract of AM. Among the known isolates, $\mathbf{1 4}$ was isolated from the Astragalus genus for the first time, and compounds 7-12, 18-20 were isolated from the species for the first time. Their structures were elucidated by chemical and spectroscopic methods. The effects of the compounds obtained from AM on glucose consumption were analyzed in differentiated L6 myotubes in vitro. As results, compounds 1, 2, 3, 7, 8, 10, 11, 14, 15 and 18 possessed significant promotion effects on glucose consumption in L6 myotubes. Among them, the activities of 1, 2 and 7 were comparable to that of insulin, which suggested that these AM compounds may be involved in glucose metabolism and transportat. On the basis of the activity results, the structure-activity was discussed. Glucose consumption plays a role in cellular energy homeostasis. This process includes glucose uptake, translocation, glucose storage, involves many key kinase, including AMP-activated protein kinase, phosphoinositide 3-kinase, glycogen synthase kinase, and so on. Further studies will be carried out to elucidate the mechanism of action of these and other kaempferol derivatives on glucose consumption.

Acknowledgments: Part of this research was supported by Programs for New Century Excellent Talents in University (NCET-12-1069), Tianjin Innovative Research Team in University (TD12-5033), and Changjiang Scholars and Innovative Research Team in University (PCSIRT IRT_14R41).

Author Contributions: Yi Zhang designed the research and wrote the manuscript; Jia Hao, Jian Li, and Xiaoxia Li performed the experimental work; Yanxia Liu retrieved literature; Jingya Ruan perfected language. All authors discussed, edited and approved the final version.

Conflicts of Interest: The authors declare no conflict of interest.

\section{References}

1. Zhang, Y.; Li, X.; Ruan, J.; Wang, T.; Dong, Y.; Hao, J.; Liu, E.; Han, L.; Gao, X.; Wang, T. Oleanane type saponins from the stems of Astragalus membranaceus (Fisch.) Bge. var. mongholicus (Bge.) Hsiao. Fitoterapia 2015, 109, 99-105. [CrossRef] [PubMed]

2. Lu, W.; Lu, G.; Tan, X.; Chen, J.; Huang, Z. Chemical constituents of Desmodium caudatum. J. Chin. Med. Mater. 2013, 36, 1953-1956.

3. Wei, J.; Chang, X.; Wang, W.; Kang, W. Chemical constituents from Lysimachia circaeoides. J. Chin. Med. Mater. 2013, 36, 1441-1443.

4. Zhao, D.; Li, D.; Wei, J.; Hua, H.; Li, Z. Isolation and structural identification of the chemical constituents from the flowers of Xanthoceras sorbifolia Bunge. J. Shenyang Pharm. Univ. 2012, 29, 514-518.

5. Xia, X.; Li, W. Chemical constituents of Lespedeza virgate. Chin. J. Exp. Tradit. Med. Formulae 2012, 18, $127-129$.

6. Lu, C.; Zhou, G.; Wang, H.; Li, Y.; Yao, X. Studies on the chemical constituents of Nerviliae fordii. J. Chin. Med. Mater. 2009, 32, 373-375.

7. Gohar, A.A. Flavonol glycosides from Cadaba glandulosa. Z. Naturforsch C 2002, 57, 216-220. [CrossRef] [PubMed]

8. Lu, C.; Zhou, G.; Wang, H.; Y, W.; Yao, X. Water-soluble constituents from Nerviliae fordii. Li Shizhen Med. Mater. Med. Res. 2010, 21, 3087-3088.

9. Cai, Q.; Wang, L.; Liu, Y.; Wang, C.; Gu, Y. Study on chemical constituents from leaves of Exochorda serratifolia. Chin. Tradit. Herb. Drugs 2012, 43, 673-675. 
10. Zhang, L.; Zhang, Y.; Chen, Y.; Jia, S.; Dai, J.; Meng, W.; Li, L.; Deng, Y. Isoflavones in leaves of Belamcanda chinensis. Nat. Prod. Res. Dev. 2011, 23, 69-71.

11. Wang, C.; Tang, Y.; Zhou, L.; Gao, H. A study on flavonoid in barks of Sophora japonica. Jiangsu Zhongyiyao 2008, 40, 65-67.

12. Zhang, S.; Fan, C.; Wang, L.; Liu, X.; Sun, X.; Ye, W. Chemical constituents of Shenqi Fuzheng Injection. Chin. Tradit. Pat. Med. 2011, 33, 1743-1747.

13. Song, C.; Zhen, Z.; Liu, D.; Hu, Z. Isoflavones from Astragalus membranaceus. Acta Bot. Sin. 1997, 39, 764-768.

14. Zheng, W.; Tan, X.Q.; Guo, L.J.; Kong, F.F.; Lu, P.; Ni, D.J.; Wang, P. Chemical constituents from Monochasma savatieri. Chin. J. Nat. Med. 2012, 10, 102-104. [CrossRef]

15. Gaffield, W. Circular dichroism, optical rotatory dispersion, and absolute configuration of flavanones, 3-hydroxyflavanones, and their glycosides. Determination of aglycone chirality in flavanone glycosides. Tetrahedron 1970, 26, 4093-4108. [CrossRef]

16. Chu, H.; He, W.; Zhang, Y.; Ji, C.; Tan, N. Flavonoids and nor-sesquiterpenes of Pedicularis densispica. China J. Chin. Mater. Med. 2011, 36, 2672-2675.

17. Otsuka, H.; Takeuchi, M.; Inoshiri, S.; Sato, T.; Yamasaki, K. Phenolic compounds from Coix lachryma-jobi var. Ma-yuen. Phytochemistry 1989, 28, 883-886. [CrossRef]

18. Lee, S.Y.; Kim, K.H.; Lee, I.K.; Lee, K.H.; Choi, S.U.; Lee, K.R. A new flavonol glycoside from Hylomecon vernalis. Arch. Pharm. Res. 2012, 35, 415-421. [CrossRef] [PubMed]

19. Ma, Z.; Fujii, I.; Ebizuka, Y.; Li, X.; Shimomak, I.S.; Sakano, Y. Flavonoids from the seeds of Sphaerophysa Salsula. J. Asian Nat. Prod. Res. 2004, 6, 69-73. [CrossRef] [PubMed]

20. Yang, D.H.; Ren, X.L.; Xu, F.; Ma, X.Q.; Liu, G.X.; Li, C.H.; Li, C.; Cai, S.Q. Absorptive constituents and their metabolites in drug-containing urine samples from Wuzhishan miniature pigs orally administered with Buyang Huanwu decoction. J. Nat. Med. 2014, 68, 11-21. [CrossRef] [PubMed]

21. Zhang, Y.; Chen, Y.; Wang, S.; Dong, Y.; Wang, T.; Qu, L.; Li, N.; Wang, T. Bioactive constituents from the aerial parts of Lippia triphylla. Molecules 2015, 20, 21946-21959. [CrossRef] [PubMed]

22. Cheong, S.H.; Furuhashi, K.; Ito, K.; Nagaoka, M.; Yonezawa, T.; Miura, Y.; Yagasaki, K. Daidzein promotes glucose uptake through glucose transporter 4 translocation to plasma membrane in L6 myocytes and improves glucose homeostasis in Type 2 diabetic model mice. J. Nutr. Biochem. 2014, 25, 136-143. [CrossRef] [PubMed]

23. Minakawa, M.; Miura, Y.; Yagasaki, K. Piceatannol, a resveratrol derivative, promotes glucose uptake through glucose transporter 4 translocation to plasma membrane in L6 myocytes and suppresses blood glucose levels in type 2 diabetic model db/db mice. Biochem. Biophys. Res. Commun. 2012, 422, 469-475. [CrossRef] [PubMed]

24. Yin, J.; Gao, Z.; Liu, D.; Liu, Z.; Ye, J. Berberine improves glucose metabolism through induction of glycolysis. Am. J. Physiol. Endocrinol. Metab. 2008, 294, E148-E156. [CrossRef] [PubMed]

Sample Availability: Samples of the compounds are available from the authors.

(C) 2016 by the authors; licensee MDPI, Basel, Switzerland. This article is an open access article distributed under the terms and conditions of the Creative Commons by Attribution (CC-BY) license (http://creativecommons.org/licenses/by/4.0/). 